\title{
Transforming power in Amazonian extractivism: historical exploitation, contemporary "fair trade", and new possibilities for indigenous cooperatives and conservation
}

\author{
Brian J. Burke ${ }^{1}$ \\ University of Georgia, USA
}

\section{Introduction}

Conservationists increasingly strive to design programs that foster community participation in natural resource management and link conservation with income-generating development activities. This turn away from the old fences and guns approach to environmental protection is rooted in concerns that top-down conservation programs that do not alter local people's incentives to exploit natural resources achieve neither ecological goals nor more general commitments to social justice, poverty reduction, and community participation. Fundamentally, this argument is supported by the position that ecological problems and solutions cannot be separated from their social, cultural, economic, and political context; the exploitation of nature and the exploitation of humans are profoundly interconnected (Bookchin 1989, Marx 1867, ch. 7; Wolf 1982: 73-74). The challenge, then, is to devise conservation measures that disrupt these linked systems of exploitation. This is no small feat.

Cooperatives have been given a similarly grandiose mission: they are meant to radically transform power relations to the benefit of marginalized people by altering labor processes, patterns of ownership, the organization of commodity chains, surplus distribution, and social support networks. It is no coincidence, therefore, that cooperatives and similar associations often serve as vehicles for community-based conservation and development. Cooperatives committed to radical social transformation, however, face a serious challenge: they must build on the present in order to change it. To succeed, cooperatives have to strike a fine balance. Those that cannot meet the demands of highly competitive markets risk financial collapse, but those that simply conform to a conventional market logic of efficiency, productivity, and expansion may become complicit in recreating inequality and marginalization, destroying natural resources, and undermining nonmarket livelihood activities. Faced with this dilemma, many cooperative managers and scholars have prioritized pragmatic questions of how to launch and sustain cooperative economic projects (Cracknell 1996, Davis 1999, Taimni 2001) and in the process, have neglected questions of history, power, and change that should be central to cooperativism.

In this paper, I re-insert questions of power and history into the discussion of cooperative-led conservation and development through an examination of AmazonCoop. This cooperative-which was dedicated to the supposedly fair trade of Brazil nuts between Amazonian indigenous people and the multinational cosmetics company The Body Shop-was founded on the hopes that extraction of non-timber forest products could promote conservation and development for indigenous people and that corporatecooperative partnerships could achieve the economic and social promises of cooperativism. Unfortunately, it was gradually destroyed between 2006 and 2007, without having accomplished many of these ideals, as a result of legal troubles, strained relations with The Body Shop, and serious power struggles among the cooperative's non-indigenous stakeholders. Nonetheless, it offers valuable lessons.

Because I have described the mixed successes and shortcomings of the cooperative elsewhere (Burke 2006, 2010), my goal here is somewhat different: to use AmazonCoop as a platform for creatively rethinking cooperative design. What types of questions can we ask of ourselves in order to create cooperatives that disrupt linked systems of social and ecological exploitation? In a sense, my goal here is to reverse a process "common to virtually all environmental issues today: the process by which the discursive and institutional contours of such issues are shifted - not inadvertently - away from the moral/political domain and toward the domain of governmentality, managerialism, and bureaucratization" (Brosius 1999: 49). Brosius blames this

\footnotetext{
${ }^{1}$ Post-Doctoral Research Assistant, Coweeta Long Term Ecological Research Project (LTER), University of Georgia, USA. Email: bburke "at" email.arizona.edu. I would like to thank the many people who made this research possible, particularly the indigenous villagers of Koatinemo, the former employees of AmazonCoop, and the Brazilian indigenous advocates and cooperative promoters who provided information and support for this research. This work formed part of the Latin American Cooperatives Project at the Bureau of Applied Research in Anthropology, University of Arizona; it was conducted under contract with the Agricultural Cooperatives Development International and Volunteers in Overseas Cooperative Assistance (ACDI/VOCA) as part of a project funded by the U.S. Agency for International Development. My participation was also supported by the Tinker Foundation. A special thanks goes to PIs Timothy J. Finan and Marcela Vásquez-León and to the other members of our research team, particularly Paola Canova and Fernando Mayorga, whose company greatly enriched my fieldwork experiences. Finally, thank you to those scholars who generously commented on earlier drafts of this paper, including J. Stephen Lansing, Drexel Woodson, Laura Zanotti, and the members of the Eric Wolf Prize Committee. This paper was joint winner of the Eric Wolf Prize, Political Ecology Society, 2011 and appears in a JPE Special Section of Eric Wolf Prize papers edited by Joe Heyman.
} 
depoliticization of conservation on what Rappaport called "institutional deafness": "the unwillingness or inability of authorities to understand messages encoded in terms other than those of the dominant economic discourse" (Rappaport 1993: 300, cited in Brosius 1999). Cooperatives stand toward the edge of that dominant discourse-often thoroughly normalized but promising the possibility of a counter-current. In this article, I challenge us to think about how alternative economic possibilities might improve the impacts of cooperatives and conservation.

In what follows, I briefly describe environmental challenges in the Brazilian Amazon and the history of AmazonCoop. I then place the cooperative's Brazil nut trade in a historical political ecological perspective in order to demonstrate how a thorough consideration of power and history can enhance cooperatives' impacts as deeply transformative change agents. A power-centered approach to cooperative design directs our attention to the noblest goal of cooperativism-which is, after all, not to establish a particular type of organization or to survive in a global economy, but rather to create more just social and economic arrangements - and suggests innovative possibilities for achieving this goal.

The research for this article began in 2005, when co-researcher Paola Canova and I conducted 38 interviews with cooperative managers, employees, and critics in the city of Altamira, and 11 additional ones with indigenous members in the indigenous Asurini village of Koatinemo. The cooperative's demise led us to cancel a return trip, but I was able to return to Altamira (though not to any of the indigenous member villages) with another research partner, Fernando Mayorga, to conduct a very brief study five years later. The views shared by former directors, employees, and members during this second research trip were generally consistent with our original analysis.

\section{Environmental degradation, conservation, and development in the Brazilian Amazon}

Intensive natural resource exploitation and an expanding agricultural frontier have created bands of severe deforestation across the Brazilian Amazon, potentially compromising the hydrological properties of the river basin and the ecosystem services that it provides. Deforestation levels exceed 14\% for the Brazilian Amazon as a whole, but vary significantly among the 10 sub-basins and 927 sub-watersheds; more than onefifth of sub-watersheds exceed the $20 \%$ deforestation level at which hydrological impacts become more significant and some are $80 \%$ deforested (Trancuso et al. 2010). To prevent further degradation and to fulfill its constitutional commitment to indigenous rights, the Brazilian government has designated $43 \%$ of the Brazilian Amazon as protected areas or indigenous lands (Walker et al. 2009). Satellite imagery shows relatively intact forest on indigenous lands (Schwartzman and Zimmerman 2005, Zimmerman et al. 2001) and suggests that indigenous reserves are as effective as strictly protected areas for preventing deforestation (Adeney, Christensen, and Pimm 2009). Deforestation may be reduced up to 20 times and forest fires up to 9 times within protected areas and indigenous lands (Nepstad et al. 2006), though these benefits vary significantly by region and size of the reserve (Adeney, Christensen, and Pimm 2009).

The Xingu River watershed-where the AmazonCoop operated-is the second most protected of the Amazon's ten sub-basins (with 56.9\% of the region under some form of conservation) but also the third most deforested (with an overall deforestation level of 17.1\%) (Trancuso et al. 2010). On the ground, this means that indigenous lands are often surrounded by highly degraded areas and face constant threats of invasion by illegal loggers and colonization by would-be agriculturalists (Fausto 2001: 99, Fisher 2000). While forests in AmazonCoop's work area are relatively well protected, protection of reserve edges remains a serious problem and intensive deforestation in the headwaters of the Xingu may have already affected hydrological and biogeochemical processes throughout the basin (Trancuso et al. 2010). In addition, indigenous people themselves have not always pursued the most environmentally friendly economic activities, granting concessions to timber and mining companies to operate within their territories (Turner 1995, Zimmerman et al. 2001). A new campaign by the government and electric companies to build the controversial and longdelayed Belo Monte hydroelectric complex just downriver from Altamira could further degrade ecosystem integrity in the region (Fearnside 2006, Manyari and de Carvalho 2007).

In 1991, The Body Shop began buying Brazil nuts from Kayapó harvesters along the Xingu River as part of a "Trade Not Aid" program to support indigenous development and rainforest conservation. These early efforts developed into the AmazonCoop, whose Brazil nut extraction program represents a relatively new current in conservation thinking rooted in the hope that ecological and social outcomes can be improved by integrating conservation and development (Agrawal and Gibson 1999, McShane and Wells 2004, West and Brockington 2006). When communities derive incomes from sustainable resource exploitation, the theory goes, they no longer need to pursue the most damaging economic activities and can be effectively integrated as resource managers (Zimmerman et al. 2001). Although increasingly popular, the real conservation and development impacts of community-based conservation are not entirely clear and have generated a heated debate (Brooks, Wright, and Sheil 2009, Naughton-Treves, Holland, and Brandon 2005, Shahabuddin and Rao 2010, Sunderland, Ehringhaus, and Campbell 2007, Wilshusen et al. 2000). What seems certain, however, is that community conservation and development work best through sustained, long-term projects that build community management capacity, support existing institutions for collective decision making and 
conflict management, balance local and exra-local control, establish clear resource rights, and proffer the resources necessary to apply those rights (Stearman 2006).

\section{AmazonCoop}

AmazonCoop (also known as CAMPEALTA) was founded in 1998 by representatives of the Fundação Nacional do Índio (Brazilian National Indian Agency-FUNAI) and the UK-based cosmetics company The Body Shop to formalize trade links between the multinational firm and Brazil nut harvesters from eight indigenous tribes. The cooperative was intended to supply The Body Shop with the raw materials and ecologically-sustainable/socially-just symbolism needed for its best-selling products, to help FUNAI protect and serve indigenous people despite neoliberal reforms that decreased funding and restricted their responsibilities, to allow indigenous people to finance their own community development, and to protect the environment by offering tribes an income-generating alternative to alliances with mining and logging companies. As a public-private partnership based on fair trade, the cooperative grew directly out of processes of neoliberal economic globalization and movements to harness (and create) markets for conservation and development.

AmazonCoop was located in Altamira, Pará, in the central region of the Brazilian Amazon. Although Altamira was important in the rubber booms at the opening of the $20^{\text {th }}$ century and during World War II, the local economy is currently supported primarily by legal and illegal logging, mining, agriculture, ranching, and the extraction of non-timber forest products such as Brazil nuts, which are the fifth most valuable non-timber forest product nationally (Instituto Brasileiro de Geografia e Estatística 2004). Most of the region's indigenous people live on indigenous reserves, where they combine subsistence activities with cash incomes from mining and logging concessions, seasonal employment in extractive industries, and government jobs, pensions, and welfare programs (Castro 1992).

AmazonCoop worked with more than 2,000 indigenous people living in 14 villages and representing eight tribes: the Arara, Araweté, Asurini, Kayapó, Parakanã, Xikrin, Curuaia, and Xypaia. ${ }^{2}$ The cooperative's income derived about equally from Brazil nut sales to The Body Shop and an Internet service provider for residents of Altamira. The cooperative also coordinated with the Amazon Rainforest Foundation to run ecoand ethno- tourism for wealthy foreigners who were encouraged to finance projects to improve education and health services and to secure the borders of one tribe's territory. Membership in the cooperative was organized at the village level, with one or two representatives from each village granted the members' right to vote in the General Assembly, but these village representatives were not elected and were scarcely accountable to their villages, and the vast majority of decisions were made by the cooperative's international advisors and nonindigenous Brazilian managers.

As I have discussed previously, the cooperative's social and economic impacts in indigenous villages were inconsistent:

AmazonCoop's international alliances certainly provided significant material benefits. The Brazil nut trading program more than doubled the annual profits of indigenous nut collectors [compared to riverside sales to other intermediaries] while steering tribes away from alliances with the more environmentally damaging mining and logging industries, and tourist-funded, cooperative-managed health and education projects further contributed to a widely supported form of development. The cooperative provided indirect benefits by supporting [government agencies, both financially and administratively]. Unfortunately, AmazonCoop also made indigenous people more vulnerable and more dependent on outsiders, failed to include them as informed participants in their own development, masked the negative effects on them of unfavorable government policies, and perpetuated discriminatory distinctions among them. (Burke 2010: 42)

Morsello (2006) and Müller (2002) have also noted that intensive dedication to more lucrative cash opportunities has disrupted traditional systems for transmitting knowledge and the performance of social and ceremonial activities among some local tribes.

Our initial analysis of AmazonCoop, based on research conducted in 2005 (Burke and Canova 2006, Burke 2006, Vasquéz-León 2006), demonstrated that global markets and international alliances provided significant economic opportunities for the cooperative and its indigenous members through increased incomes and support for new infrastructure. However, it also showed that successful cooperative economies guarantee neither genuine cooperativism, nor social development, nor transformation of the structural conditions that maintain marginalization. In particular, we raised serious concerns about AmazonCoop's structure and its success in altering the deep inequalities of Brazilian society. Cooperative managers and members failed to

\footnotetext{
${ }^{2}$ For consistency, I use the same ethnic categories as AmazonCoop. The Xikrin, however, are considered to be members of the larger Kayapó ethnic group (though they are somewhat distinct from other Kayapó groups) and the degree of involvement of the Xypaia and Curuaia in the cooperative was unclear.
} 
translate the guiding cooperative principles of democracy, participation, autonomy, and self-sufficiency into action. They fostered neither liberal, Western-style democratic participation nor indigenous forms of selfgovernance. As such, indigenous people in the region remained passive beneficiaries subject to the decisions and desires of the cooperative's international advisors and the local, non-indigenous cooperative staff, including the director of FUNAI-Altamira. AmazonCoop also did not base its Brazil nut extraction goals on an analysis of maximum sustained yields, privileging instead the yearly needs of The Body Shop. The lack of indigenous participation raised concerns - which were eventually borne out-about the cooperative's sustainability. This cooperative certainly did not develop into the long-term, community-led, capacitybuilding institution that seems necessary to make community-based conservation and development work.

In the next section, I consider the cooperative from a slightly different perspective. By examining AmazonCoop in the light of indigenous people's involvement in historical extractive economies in the Brazilian Amazon, I analyze how the cooperative altered the regional political economy, sources of indigenous power, and patterns of exploitation of indigenous people and the environment.

\section{Historical struggles in Amazonian extractivism}

The contemporary globalization underlying AmazonCoop's work has deep historical precedents in the Brazilian Amazon. For almost four centuries, the resource-rich Amazon has been a source of wealth for colonial and capitalist systems, and the resulting extractive industries have been important sites of political and economic negotiation among Amazonian indigenous people, non-indigenous Brazilians, local and foreign commercial interests, and the state. To a large degree, efforts to exploit natural resources have structured the exploitation of social groups as well. Understanding the impacts of AmazonCoop requires that we investigate the history of Amazonian extractivism, and particularly the history of the rubber industry. Three features of the rubber industry are especially important for this discussion: the involvement of indigenous people, the organization of extraction through the aviamento debt-peonage system, and the recurrence of the aviamento system in Amazonian political-economic organization throughout the $20^{\text {th }}$ century.

The Amazon presented would-be rubber barons with a number of serious obstacles. As Bunker (1984) explains, each mode of extraction in the region has been shaped by the social and ecological legacies of previous extractive projects. The late $19^{\text {th }}$ century elite could not easily respond to nearly insatiable rubber demand because the colonial-era spice and animal oil trades had degraded ecosystems, decimated the local, indigenous labor pool, and encouraged survivors to flee to upland areas from which they could more effectively control contact with Euro-Brazilians. To capitalize on new global markets and the high quality of Brazilian rubber, the elite were forced to import tens of thousands of workers, mostly from the droughtburdened and famine-plagued state of Ceará.

If importing laborers was difficult, ecological and economic barriers posed even greater problems. Seringalistas (rubber bosses) struggled to make a profit despite volatile world prices while using imported, impoverished, and inexperienced laborers to collect widely-dispersed wild rubber in "what may [have been] the most inaccessible area in all of Brazil" (Nimuendajú 1920: 149). They faced high costs related to river transport, numerous intermediaries between tapping and export, and the provisioning of tappers so that they could dedicate themselves to rubber collection rather than subsistence. They also faced high risks of losing their product on dangerous rivers, losing upwards of $50 \%$ of their tappers to disease and desertion, losing profits due to unfavorable exchange rates and rapidly changing prices at export houses, and being cheated when workers covertly sold rubber to itinerant traders (Barham and Coomes 1994).

The infamous aviamento debt-peonage system effectively overcame these obstacles to economic organization. Through this system, rubber tappers were transported into the Amazon and advanced supplies at the beginning of each season with the expectation that they repay these debts in rubber. Seringalistas set the terms of trade and in many cases used extreme violence to ensure payment. Minor seringalistas entered into similar arrangements with larger ones, and larger ones with the export houses that ultimately controlled prices and credit. Tappers, located at the bottom of the debt and pricing pyramid, paid as much as $250-500 \%$ above city prices for basic goods and received less than $50 \%$ of going prices for their rubber (Barham and Coomes 1994).

Indigenous Amazonians were profoundly, though not uniformly, affected by the rubber boom, particularly as tappers invaded upland areas in search of caucho trees and forced indigenous populations to flee, resist, or join the rubber economy as willing and unwilling laborers. Some tribes fell prey to disease and a "slow and cruel war of extermination" (Nimuendajú 1920: 146). The Kayapó-Gorotire, for example, were attacked by rubber tappers after an initial period of peace and forced to migrate several times, sparking a longstanding war against the tappers of the Xingu, Fresco, Iriri and Curua Rivers. The Gorotire were so haunting that Fisher reports Brazilians shouting "Gorotire!" to scare their children into good behavior (2000: 42). Other tribes worked with rubber tappers to identify trees, defend territories against competitors, and provide food in times of need, all in exchange for manufactured goods (Fisher 2000). Participation in the rubber economy led to significant changes in the gendered division of labor, social organization, patterns of household residence, property ownership, and resource management (Wolf 1982: 326-329). The uneven introduction of foreign weapons affected inter-tribal power dynamics, forcing some tribes to migrate away from their well-armed neighbors. Enterprising seringalistas often exploited inter-tribal tensions, arming and paying "pacified" tribes 
to attack and sometimes enslave those who posed a greater threat to extractivism (Nimuendajú 1920: 152). A different Kayapó group, however, "had the rare fortune of making their first contact with well-intentioned civilized people" and thereby "escaped from extermination by iron and fire, which was the fate of the others during the great advance of the caucho rubber tappers in this region" (Nimuendajú 1920: 147). Their good luck was not the norm.

North of the Kayapó (in the AmazonCoop area), government Indian scout Curt Nimuendajú found the "leftovers of tribes, meager wastes that the wave of caucho rubber tappers did not drown in its brutal advance" (Nimuendajú 1920: 150). The Asurini "appeared" in 1894 and immediately launched a war against the "civilized people," maintaining an area between the Xingu and Pacajá rivers by attacking on both sides. But the seringalistas armed and paid the "pacified" Arara to attack the Asurini, reducing their numbers and power significantly. Nimuendajú described the Arara and the remaining Xipaya and Curuaia as "belonging to" different white settlers, a relationship that he says saved the latter groups from the full onslaught of the rubber tappers, but also forced some Xipaya into "conditions that can only be clearly characterized by one Portuguese word: slavery" (Nimuendajú 1920: 152). The Juruna, once the most important tribe of the Xingu region, were attacked, forced to migrate, and attacked again before finally establishing peaceful relations with a rubber tapper who took several leaders to Altamira. Most of the travelers died in the city, and the survivors fled into the forest.

After the Brazilian rubber industry collapsed due to market instability and competition from more efficient, disease-resistant Southeast Asian plantations (Frank and Musacchio 2006), many indigenous people fled to more secure upland areas and non-indigenous people migrated in search of other economic opportunities. But the aviamento system continued to organize Amazonian labor and commodity flows, including the extraction of Brazil nuts, through the middle of the $20^{\text {th }}$ century (Laraia and da Matta 1967). Aviamento remained a "rational" way of organizing and controlling scarce labor and capital in an Amazonian ecological context, and had likely become a fairly hegemonic template for social and economic organization. Of course, relations among regional elite and between the elite, intermediaries, and extractivists have certainly changed over time (see, for example, the discussion in Weinstein 1983), but one hundred years of patronclient networks organized around the aviamento system likely made it difficult to conceive of viable alternatives, let alone establish them against entrenched interests.

The case of the Kayapó Xikrin demonstrates the continuity and institutionalization of the aviamento system and the importance of extractivism in regional political economies. After years of disrupting local extractive efforts, the Xikrin were "pacified" at the end of the 1950s, integrated by government officials into the international fur trade under the aviamento model, and used to fight and settle the Asurini and Araweté, who were also seen as threats to extractivism. Fisher (2000) notes that the Xikrin entered the fur trade to meet their own goals, not simply because of government coercion. Government-issued firearms offered security after several decades of war and migration, and long treks in search of furs allowed Xikrin families to avoid sad and dangerous reunions with the spirits of the many ancestors who died during contact and lingered in villages. In many ways, the Xikrin think of the fur boom as a golden age of peace, security, and impressive access to goods. With its own source of goods, the tribe was not vulnerable to the vagaries of government budgets. However, the international ban on the fur trade generated that vulnerability and prompted the government and tribe to reorient their efforts around Brazil nut collection.

While the Brazilian state played little direct role in the rubber trade (it played a very large indirect role), it has entwined itself in contemporary manifestations of the aviamento system as an intermediary. By the 1970s, FUNAI had "pacified" and "villagized" many of Altamira's indigenous people and had drawn them back into extractivism through trade in fur and Brazil nuts. By mediating indigenous peoples' involvement in extractivism, FUNAI used indigenous labor to underwrite its own operating costs and established itself as a powerful supplier of manufactured goods. Extractivism turned indigenous groups into "self-financing and dependent communit[ies] . . . initiated into a system that [has] been in existence since the rubber boom in Amazonia, a system still widely practiced on Indian posts" (Fisher 2000: 77). In this context, however, FUNAI's authority is largely dependent on fluctuations in the world market in non-timber forest products. Writing just as AmazonCoop was being founded, Fisher (2000) describes the Brazil nut harvest as "a calculated gamble" and "a time of great anxiety" for Xikrin villagers (78).

Extractivism creates a delicate and competitive set of alliances among Amazonian indigenous peoples, FUNAI, and corporations. Goods and services serve as critical forms of currency that make those alliances possible. Non-indigenous people seek raw materials such as spices, rubber, fur, timber, minerals and Brazil nuts, and they depend on a predictable and controlled labor process to obtain these goods. Manufactured debt and direct government mandates shape indigenous people into "useful" extractivists. For their part, indigenous people seek manufactured goods and development projects that, in addition to their instrumental value, have the political value of reinforcing the power of chiefs as intermediaries with the white world and redistributors of trade goods. These material bases of chiefly power have become especially important because the dispersed and family-based nature of extractivism has weakened chiefs' traditional roles as organizers of communal labor (Fisher 2000).

Fisher's account of Kayapó-Xikrin involvement in extractivism is particularly rich because it explains the sources of indigenous people's power and agency in these negotiations and conflicts: their labor power, 
ecological knowledge, ability to disrupt non-indigenous economies, and ability to fall back on traditional hunting-planting-gathering livelihoods that permit relative autonomy. Indigenous people have been a resource and threat to extractive industries, and they have generally remained resilient to economic booms and busts. Their ability to shift between government and corporate partners has also been helpful; for example, a downturn in the FUNAI-organized Brazil nut trade in the late 1990s encouraged tribes to fulfill their demand for goods through alliances with mining and timber firms. This is where the story of AmazonCoop begins.

Like previous extractive projects in the region, AmazonCoop grew from the convergence of foreign demand and local and international entrepreneurship. Through the cooperative, indigenous people, corporations, and the state sought to capitalize on local natural resources within the political and economic context of globalization and neoliberal policies. The cooperative's adaptations, like those of $19^{\text {th }}$ century seringalistas, were shaped by previous extractive projects. AmazonCoop was established in a region structured around the old aviamento system, where indigenous people and other extractivists have often been controlled by debt and violence in a nearly lawless land, and where they typically occupied the most unfavorable position within a value chain controlled by foreigners and a large number of intermediaries. Worse, while indigenous people historically found power in their ability to provide or withhold critical knowledge, to play competing firms against each other, to violently disrupt the riverine trade of rubber and basic necessities, and to return to traditional means of subsistence, state-led "pacification" and "villagization" now limited many of these avenues for indigenous power.

I do not want to overstate the historical continuities, however. In addition to this historical legacy, AmazonCoop also embodies several distinctive features of contemporary society, most notably the prominence of international civil society, new niche markets for socially responsible and environmentally sustainable consumer goods, and the improved legal and social status of indigenous people in Brazil and beyond. Further, as Turner (1995) describes for the more politically active upriver Kayapó, the expansion of timber and mining operations on indigenous territories since the 1970s offers a slightly different model of economic organization and has given rise to a new class of leaders whose power derives from inter-cultural mediation. At the same time, these leaders' complicity in ecological and economic exploitation launched the upriver Kayapó's "revolt against extractivism," a revolt that demonstrates that violence and intimidation can remain effective for opposing even wealthy gold and timber operations, the Brazilian government, and emergent indigenous elite who violate community norms. As Turner wrote, "traditional institutional structures of political and ritual authority may continue to play a vital and constructive role in the struggle of indigenous people to forge innovative social and political solutions to the problems of inter-ethnic coexistence and capitalist environmental exploitation" (1995: 118). All of these developments-the continued relevance of traditional institutions, new sources of power related to international concern for indigenous people and rainforest conservation, the emergence of different labor systems-suggest openings for changing local political ecologies.

\section{Contemporary and historical extractivism in the Brazilian Amazon: analyzing AmazonCoop as an agent of change}

Given the long history of divide-and-conquer tactics and indigenous marginalization within Amazonian commodity chains, cooperative organizations seem to be a promising addition to the extractivist economic landscape in this region. Cooperatives are meant to benefit members by changing their position within production, marketing, and/or consumption systems. By drawing members together in a single institution, they can provide important benefits like economies of scale; access to credit, capital, and machinery; possibilities for providing social services en masse; reduced dependency on outsiders; and the ability of members to mobilize and exert political influence. As grassroots, participatory, and democratic institutions, they are also supposed to be highly responsive to the social dynamics and cultural values of members. In our previous research, we have shown that the AmazonCoop trade relationship did provide significant material benefits to indigenous extractivists in Altamira. By combining vertical integration with The Body Shop's above-market price, the cooperative was able to pay indigenous harvesters more than double the local rate for riverside purchases of Brazil nut.

However, I argue that if cooperatives are to be agents of change, they must do more than help members benefit from existing political economies; they must also change unjust patterns of power and exploitation within those political economies. To what extent did AmazonCoop change historical relations of power, control, and exploitation? On the surface, the (non-indigenous) cooperative directors seemed to be on the right track. They listed self-sufficiency, cultural integrity, and the ability to engage effectively with "o mundo branco" (the white world) as their most important goals for indigenous members. The cooperative's success in vertical integration of the rubber industry and economic diversification (results of large infusions of foreign capital) also seemed promising. Unlike the rubber tappers of the past, the cooperative was able to eliminate several intermediaries by purchasing its own cargo boat, warehouse, and an oil-processing plant. This ensured a larger profit and fewer risks, and therefore reduced the need for extreme exploitation and violence.

On closer examination, however, AmazonCoop reproduced many historical relations of control and exploitation without enhancing the bases of indigenous people's power. The continuities in Amazonian extractivism are particularly evident in the organization of Brazil nut collection. As with previous modes of 
extraction, the Brazil nut trade was internationally oriented, with a market structure determined by forces outside of Brazil and its indigenous communities. The costs, risks, and difficulties of Brazil nut extraction resembled those of rubber (though they were less extreme) and the cooperative's extractive program was organized along the lines of previous FUNAI programs, which were themselves variations of the aviamento system. Laborers were controlled by the cooperative's and FUNAI's near monopoly on manufactured goods and development projects, by debt accrued through advanced supplies, and by strong government control over indigenous villages.

AmazonCoop's Brazil nuts were harvested directly from the forest, a difficult, time-consuming, and dangerous process. In most member villages, the nuts were collected in February and March by individual families, some of whom spent the entire two-month harvest season in the forest. Traveling to distant Brazil nut patches requires a significant investment of time and money for inputs such as gasoline, food, and hunting and fishing supplies. To offset these costs and encourage intensive dedication to Brazil nuts, the cooperative advanced money and supplies at the start of each harvest season, which harvesters repaid in nuts. The extractivists we interviewed gave mixed reviews of this credit system, complaining about low end-of-season profits but content with the higher yields made possible by more time in the forest. Long absences seemed to threaten family agricultural production, however, and may have decreased food quality. One Asurini family dedicated themselves so intensively to Brazil nuts that they did not grow their own farinha (yuca or manioc meal), marking the first time that anyone could remember a family lacking this staple food. Though not as exploitative as the traditional aviamento system, AmazonCoop's credit system created dependencies on the cooperative, the government, and the Brazil nut harvest by encouraging extraction at the expense of other livelihood options.

If the cooperative had been owned and operated by its indigenous members, this manner of organizing extractivism would have been a significant change from the aviamento system: indigenous harvesters would suddenly have controlled the capital, credit, and equipment that shaped their work, and their production of Brazil nut oil would have moved them up the value chain. Unfortunately, however, AmazonCoop was a topheavy organization in which power and decision-making authority were concentrated not only outside of indigenous villages but also outside of Brazil. The cooperative's use of "them" in public references to indigenous members is revealing in this regard. AmazonCoop was an organization of non-indigenous advocates acting on behalf of the indigenous people of the Altamira region and in the interest of a multinational corporation and a government agency. The cooperative's strategy was devised by an international advisory board comprised of representatives from multinational corporations and leaders of the corporate social responsibility movement. This strategy was then handed down to an administrative council whose active members were all non-indigenous Brazilians. It was only through village representatives to the General Assembly that indigenous people were involved in decision making, but assemblies were rarely held and a quorum required the presence of as few as three indigenous people. In addition, the cooperative's three main income sources-Brazil nut sales, the provision of Internet services, and donations via the Tataquara Eco-Lodge-all depended on non-indigenous managers, international capital, and (with the exception of the Internet) foreign markets. Indigenous people had virtually no say in the organization of these economic projects and controlled none of the assets on which they depended.

AmazonCoop probably did not choose this international orientation for the purpose of maintaining the dependency of indigenous members. In addition to extremely low levels of formal education and professional management experience in Altamira's indigenous villages, there were several good reasons that the cooperative founders might have looked abroad for support. The cooperative was founded by non-indigenous entities-The Body Shop and the regional FUNAI administration-to meet the material, financial, and marketing needs of those entities. In addition, this strategy was an economically rational response to the cooperative's ability to mobilize significant levels of foreign capital from countries where indigenous Amazonians have high symbolic power, and the difficulties of finding domestic support due to antiindigenous racism. Finally, the cooperative emphasized international partnerships because, in the view of its managers, the Brazilian state had failed to provide adequate support for indigenous people. Nonetheless, while international links facilitated access to new markets, funding sources, and expertise, they did little to eliminate the dependencies and power imbalances of previous extractive systems.

In fact, the cooperative decreased many of the traditional sources of indigenous power within extractive economies. By integrating indigenous people, the state, and corporate interests into a single institution, it reduced competition between corporations and the state and limited opportunities for indigenous groups to play outsiders against one another. That it eliminated competition without securing a long-term commitment from The Body Shop made the economic benefits of this "fair trade" system even more precarious, giving this conservation and development project a boom/bust logic that cannot be considered sustainable in any sense of the word. In addition, because indigenous labor contributed to less than half of the cooperative's total income (the Internet service provider was equally lucrative), villagers' ability to use slowdowns and strikes to pressure cooperative directors was limited. The extent of government control over indigenous villages, development and social service opportunities, and the cooperative further enforced indigenous people's compliance with the cooperative's labor demands. 
The final days of the cooperative revealed the full extent of indigenous disempowerment. In the dramatic conflicts that led to the cooperative's dissolution, the organization's enormous debts and legal liabilities were transferred to a newly-appointed indigenous president while a sizeable portion of machinery and other assets mysteriously disappeared or were transferred to non-indigenous people. Indigenous people not only lacked effective decision-making power; even the collective nature of cooperative economic resources was a farce. Given this, the cooperative can best be seen as a new intermediary in an aviamento-like system. Rather than enabling indigenous people to control their own capital, credit, and labor, it maintained indigenous people at the lowest rungs of the production chain, albeit with better compensation.

Of course, better compensation and decreased exploitation are important gains and the indigenous villagers that we spoke with were clearly happy with the higher incomes that the cooperative permitted. My point is simply that these benefits were secured through the workings of a highly unequal society and did not entail a change in indigenous people's position within local power relations. Furthermore, many of these benefits depended more on external factors than on the cooperative itself. For example, because Brazil nuts have a shorter harvest season and constitute a much smaller industry than rubber, harvesters were able to pursue other subsistence activities and were less likely to become dependent on this single commodity and the intermediaries who controlled its sale. Also, the security of a "pacified," government-monitored, indigenous labor pool lowered economic risks and the need for more extreme forms of labor control. Most importantly, though, the main value of the cooperative's Brazil nuts derived not from their use-value but from their symbolism, from the positive image associated with fair trade, indigenous rights, and rainforest preservation. This fact altered the industry, establishing a limit to the exploitability of indigenous people and obliging corporate and state partners to provide (or at least appear to provide) something recognizable as "development."

\section{Considering power and history in cooperative design}

By now it should be clear that AmazonCoop provided economic benefits to indigenous people in the Altamira region, but it did not change (or even attempt to change) their extreme marginalization within networks of power. Unfortunately, this is not an unusual outcome of cooperatives and conservationdevelopment. The AmazonCoop story can be useful, however, for reimagining how we might transform cooperatives from mere vehicles for conservation and development into agents of profound social change.

The key, I think, lies in the way that we think about cooperative design. If we focus on creating cooperatives that can successfully execute economic projects, that is precisely what we will get: cooperatives that execute economic projects, marginally improve people's well-being, and perhaps decrease incentives for more environmentally damaging activities. This work is important, but these cooperatives will tend to work within —and therefore reproduce - the power dynamics that have created today's vastly unequal world. What if we design cooperatives based on a different set of questions? What if, instead of (or alongside of) the standard question of how to organize economically viable cooperatives, we also thoroughly interrogate how our cooperatives can challenge the historical relations of power that have structured the exploitation of people and the environment?

AmazonCoop provides a useful example for how cooperatives might be designed differently. The founders of AmazonCoop asked: "What type of organization do we need to create in order to trade with those multinational corporations that will pay a premium in order to appear fair and just?" This question is perfectly reasonable, but it reduces indigenous people's interests to the narrow issue of achieving a higher price for their products. It also puts multinational corporations in the driver's seat by emphasizing the need to adapt to their demands and the scale and speed of their operations, and it diverts attention away from critical reflection on the status quo.

Instead, we might have focused the design of AmazonCoop on the priorities of the socially, economically, and politically marginalized indigenous people that it was supposed to represent. As Zanotti (2009) demonstrates, the Kayapó (and, I suspect, probably other local indigenous groups with similar historical experiences) evaluate economic opportunities according to a complex set of social, economic, and ecological factors. According to them, a high quality commercial project: (i) generates a long-term income source, (ii) permits the pursuit of subsistence activities, (iii) requires participation across the community (to counter the production of inequalities), (iv) builds on existing land use and subsistence practices, (v) utilizes existing social institutions (rather than replacing or competing with them), (vi) promotes inter-village collaboration and alliance-building, (vii) strengthens community-outsider partnerships, (viii) minimally alters the village landscape, (ix) builds community capacity to avoid dependency on outsiders, and (x) generates minimal environmental impacts in order to not interfere with subsistence and ceremonial needs. Many of these concerns actually favor a cooperative-corporate alliance for the Brazil nut trade, but not under any circumstances. The key is to understand not only what type of alliance will work (the question the founders asked), but more importantly what type of alliance will work for the cooperative members.

Furthermore, if we intended AmazonCoop to alter local power relations, we might have placed this new possibility of cooperative-based fair trade into the historical context of indigenous involvement in extractivism, asking how it could alter the resources, challenges, and vulnerabilities that shape indigenous people's social and economic opportunities and how it could alter systems of environmental exploitation. 
While there are many ways to approach this discussion, I offer the following questions as one path for considering how historical power relations can be mobilized and changed in order to promote indigenous well being and environmental sustainability today:

1. How can indigenous people use this cooperative to preserve and expand historical sources of power in extractive economies?

2. How can indigenous people use this cooperative to mobilize new types of power available in today's global economic and social landscape?

3. How can indigenous people use this cooperative to avoid, escape, or change the dynamics that have contributed to their unfavorable position in extractive economies? How can they use the cooperative to develop more power over the forms of extraction that affect them?

These questions clearly establish that the cooperative is not an end in itself, but rather a tool that indigenous people might use to combat their systematic marginalization. By making power central to cooperative design, they help us look beyond the ways that indigenous people can use the cooperative to make in-roads with a multinational corporation willing to pay a premium for the right to use indigenous, environmental, and fair trade symbolism; they also prompt us to think about how indigenous people can carve out power within that trade relationship and how they can leverage that relationship to make broader claims to power.

Examining the old aviamento system, it is clear that a lack of capital maintained indigenous people in the lowest links of the commodity chain. A genuinely participatory cooperative would create the possibility of indigenous-controlled credit to support the Brazil nut harvest and indigenous-owned transportation and processing plants. These new commons would surely improve the position of indigenous people within the commodity chain, but the series of questions that I propose raise other possibilities as well.

For example, history shows that indigenous people sometimes resorted to extreme measuresdisrupting trade through violent river closures or leaving the rubber trade altogether-in order to force consideration of their interests. This historical understanding could be used to ensure that any new cooperative actively privileges indigenous interests. First, we might institutionalize frequent and meaningful opportunities for indigenous people to express their interests in ways that do not disrupt trade, for example through regular meetings on indigenous lands. But a cooperative that seeks to actively challenge power hierarchies might take a second, more unusual step of valuing and even strengthening indigenous people's ability to disrupt trade. Similar to "blocking" in a consensus process, this type of ultimate veto power-which could be established through a number of different mechanisms-would subordinate the cooperative economic project to the broader goal of indigenous empowerment. ${ }^{3}$ The cooperative might also strengthen indigenous power vis-à-vis international partners and other local economic elites (including the government) by using profits to strengthen traditional subsistence systems, pursue new livelihood options, and increase human capital, thus decreasing dependency on individual industries and partners. Not incidentally, designing these possibilities for protest into the cooperative might actually stabilize (rather than threaten) international partnerships by decreasing the risk of unexpected and more dramatic forms of resistance. If indigenous people have the power to demand meaningful dialogue, they don't need to assert their power through violence, intimidation, symbolic protests, and media attacks against unresponsive partners.

This brings us to the second question: how the cooperative might use contemporary developments to promote change. AmazonCoop was founded on the new symbolic value of indigenous people and the interest of international civil society in indigenous rights and conservation, but these resources were used only to increase profits to The Body Shop and earnings for indigenous harvesters. The lack of engagement with indigenous political movements is especially surprising given that the initial idea for The Body Shop's

\footnotetext{
3 This type of veto power might address the (often unintended) reproduction of inequalities through apparently fair and participatory discursive dynamics, a problem raised in a number of recent studies of transnational environmental partnerships and collaborative resource management projects. For example, Taddei (2011) describes how participatory water management programs in Brazil became structured around the technical language and knowledge that accompanied modernization, democratization and neoliberalism. This delegitimized other types of knowledge and other concerns and thereby excluded people not versed in technical jargon or comfortable with cross-class communication. It also neutralized fundamental disagreements about the process by channeling them through the process itself; critiques of the system were permitted within this purportedly neutral, liberal space of "free expression" but they often lost their effect because, in order to influence decision making, they had to be articulated in the dominant technical language. Thus, participatory processes "can be tools in the construction of the hegemony of certain discourses over others" (Taddei 2011: 120), and there is good reason to believe that they will, more often than not, privilege the discourses of transnational "mediators" (Chernela 2005) or local groups with "superior power and knowledge" (Jacobs et al., 2010). Taddei's study of participatory water management overlaps significantly with Haenn's (2005) analysis of problems with participatory forest conservation and development. Based on these and other cases, I argue that participatory processes must not only seek to integrate different kinds of knowledge (Jacobs, et al. 2010), but must also design into their process (a) a continual challenging of their own hegemonic understandings and (b) opportunities for participants to effectively contest and disrupt the process itself in order to force consensus. Otherwise, the intended participants may end up "being participated."
} 
involvement in the region grew out of a masterfully executed symbolic protest by local indigenous people against the Monte Belo hydroelectric dam. A lucrative project like the AmazonCoop Brazil nut trade might lend extra weight to indigenous demands that the Brazilian government uphold basic rights, particularly in areas like land rights and education, which become (monetarily) valuable prerequisites for foreign direct investment. This type of project could also be used to unite tribes that were previously divided (and exploited through their division) and to form mutually beneficial relationships between urban and rural indigenous people. Achieving these goals would require the dedication of time and resources to inter-village alliance building, an expensive prospect given the costs of long-distance riverine or air travel among villages but one that would pay off in socio-political benefits.

In terms of direct ecological actions, indigenous people in the region might consider how alternative market practices (such as fair trade in non-timber forest products and payment for ecosystem services such as carbon sequestration) might be yoked to alternative, non-capitalist systems of decision making and surplus management. For example, the profits generated by a cooperative could be used not to enhance personal incomes but to buy and reforest degraded land along tributaries of the Xingu and pay for stronger enforcement of reserve boundaries. While no cooperative will generate an income sufficient to eliminate economic pressures on reserve boundaries, alliances among tribes, ranchers, farmers, and conservationists have been promising (Schwartzman and Zimmerman 2005); the cooperative could facilitate these types of alliances. Finally, we might consider how the cooperative can be used to develop a more effective indigenous environmental politics. Investments in education and alliance building might increase their ability to integrate their own knowledge and rights claims with those of transnational supporters and the Brazilian government (something McCormick 2011 has identified as important) and move toward the "justice perspective" that Haenn (2005) considers central to a "sustaining conservation."

These ideas offer a hint of the possibilities that emerge when we consider cooperatives as agents of change rather than more limited economic projects, and when we place them in their historical context. They are not prescriptions. Ultimately, transformative action will depend on sincere dialogue and collaborative action among indigenous people and outside scholars and activists. Of course, most cooperatives will not be able to launch entirely new modes of production, extraction, exchange, and distribution. Historical relations of exploitation, dependency, and unequal exchange may be so entrenched that cooperative members cannot create a radically new alternative all at once. In fact, some of that resistance will come from cooperators themselves; developing an inter-tribal cooperative in the Altamira region could challenge traditional systems of chiefly power and authority, and similar projects in other rural areas might provoke similar challenges. But these sticking points only underscore the importance of more transformative cooperatives. They raise a final question that could aid in rethinking cooperatives:

4. How can cooperative members engage in these still-imperfect, still-exploitative economic practices in ways that promote their long-term liberation from systems of exploitation?

Change will not come overnight, neither in cooperatives nor in society at large. Many new AmazonCoop's will be created, projects that don't challenge the status quo but do improve living conditions for the economically disenfranchised by offering them slightly higher profits and added social perks at a lower ecological cost. These remain valuable, but I think that cooperatives can aspire to more. Through critical interrogations of power and history, I think cooperatives can help us imagine and move toward a more profound reconfiguration of power in the future. This is surely a worthwhile task.

\section{References}

Adeney, J. M., N. L. Christensen, Jr., and S. L. Pimm. 2009. Reserves protect against deforestation fires in the Amazon. PLoS ONE 4:e5014.

Agrawal, A., and C. C. Gibson. 1999. Enchantment and disenchantment: the role of community in natural resource conservation. World Development 27(4):629-649.

Barham, B., and O. Coomes. 1994. Wild rubber: industrial organisation and the microeconomics of extraction during the Amazon rubber boom (1860-1920). Journal of Latin American Studies 26:37-72.

Bookchin, M. 1989. Remaking society. Montreal: Black Rose Books.

Brooks, T. M., S. J. Wright, and D. Sheil. 2009. Evaluating the success of conservation actions in safeguarding tropical forest biodiversity. Conservation Biology 23:1448-1457.

Brosius, J. P. 1999. Green dots, pink hearts: displacing politics from the Malaysian rain forest. American Anthropologist 101:36-57.

Bunker, S. G. 1984. Modes of extraction, unequal exchange, and the progressive underdevelopment of an extreme periphery: the Brazilian Amazon, 1600-1800. The American Journal of Sociology 89:10171064. 
Burke, B., and P. Canova. 2006. AmazonCoop case study (Altamira, Pará, Brazil). Report submitted to ACDI/VOCA. Rural Cooperatives in Latin America: a study of change strategies. Tucson: Bureau of Applied Research in Anthropology, University of Arizona.

Burke, B. J. 2006. Indigenous cooperatives, corporations, and the state on Brazil's extractive frontier: contemporary and historical globalizations. MA Thesis, University of Arizona.

—. 2010. Cooperatives for "Fair Globalization"? Indigenous people, cooperatives, and corporate social responsibility in the Brazilian Amazon. Latin American Perspectives 37:30-52.

Castro, E. V. d. 1992. Araweté: o povo do Ipixuna. São Paulo: Centro Ecumênico de Documentação e Informação.

Chernela, Janet. 2005. The politics of mediation: local-global interactions in the Central Amazon of Brazil. American Anthropologist 107(4):620-631.

Cracknell, M. 1996. Cooperatives in the context of globalization and liberalization. SDdimensions. Sustainable Development Department, United Nations Food and Agriculture Organization (FAO). Online: http://www.fao.org/sd/rodirect/ROan0001.htmDavis, P. D. 1999. Managing the cooperative difference: a survey of the application of modern management practices in the cooperative context. Geneva: Cooperative Branch, International Labour Office.

Fausto, C. 2001. Inimigos Fiéis: história, guerra, e xamanismo na Amazônia. São Paulo: Editora da Universidade de São Paulo.

Fearnside, P. M. 2006. Dams in the Amazon: Belo Monte and Brazil's hydroelectric development of the Xingu River basin. Environmental Management 38:16-27.

Fisher, W. H. 2000. Rain forest exchanges: industry and community on an Amazonian frontier. Smithsonian Series in Ethnographic Inquiry. Washington, DC: Smithsonian Institute Press.

Frank, Z., and A. Musacchio. 2006. Brazil in the international rubber trade, 1870-1930. In S. Topik, C. Marichal, and Z. Frank (eds.) From silver to cocaine: Latin American commodity chains and the building of the world economy, 1500-2000. Durham: Duke University Press. pp. 271-299.

Haenn, N. 2005. Fields of power, forests of discontent: culture, conservation, and the state in Mexico. Tucson: University of Arizona Press.

Instituto Brasileiro de Geografia e Estatística. 2004. Produção do extração vegetal e da silvicultura. Vol. 19. Rio de Janeiro: Instituto Brasileiro de Geografia e Estatística.

Jacobs, K., L. Lebel, J. Buizer, L. Addams, P. Matson, E. McCullough, P. Garden, G. Saliba, and T. Finan. 2010. Linking knowledge with action in the pursuit of sustainable water-resources management. Proceedings of the National Academy of Sciences of the United States of America. Published ahead of print January 11, 2010. doi: 10.1073/pnas.0813125107.

Laraia, R. d. B., and R. da Matta. 1967. Índios e Castanheiros: a emprêsa extrativa e os índios no médio Tocantins. corpo e alma do Brasil. São Paulo: Difusão Européia do Livro.

Manyari, W. V., and O. A. J. de Carvalho. 2007. Environmental considerations in energy planning for the Amazon region: downstream effects of dams. Energy Policy 35:6526-6534.

Marx, K. 1867. Capital. Vol. 3. Hamburg: Verlag von Otto Meissner [Online version by Marx/Engels Internet Archive (marxists.org) 1995, 1999].

McCormick, S. 2011. Damming the Amazon: local movements and transnational struggles over water. Society \& Natural Resources 24:34-48.

McShane, T. O., and M. P. Wells. 2004. Getting biodiversity projects to work: towards more effective conservation and development. New York: Columbia University Press.

Morsello, C. 2006. Company-community non-timber forest product deals in the Brazilian Amazon: a review of opportunities and problems. Forest Policy and Economics 8:485-494.

Müller, R. P. 2002. "Asurini," in Enciclopêdia dos povos Indígenas. Belem: Instituto Socioambiental.

Naughton-Treves, L., M. B. Holland, and K. Brandon. 2005. The role of protected areas in conserving biodiversity and sustaining local livelihoods. Annual Review of Environment and Resources 30: 219252.

Nepstad, D., S. Schwartzman, B. Bamberger, M. Santilli, D. Ray, P. Schlesinger, P. Lefebvre, A. Alencar, E. Prinz, G. Fiske, and A. Rolla. 2006. Inhibition of Amazon deforestation and fire by parks and indigenous lands. Conservation Biology 20:65-73.

Nimuendajú, C. 1920. Cartas de Belém. Letter to: Ílmo. Sr. Dr. Luiz Bueno Horta Barboso, Diretor do Serviço do Proteção dos Índios. 23 de Julho de 1920. In Etnografia e Indigenismo: Sobre os Kaingang, os Ofaié-Xavante, e os Índios do Pará. Edited by C. Nimuendajú and M. A. Gonçalves, pp. 141-154. São Paulo: Universidad de Campinas.

Rappaport, R. A. 1993. Distinguished lecture in general anthropology: the anthropology of trouble. American Anthropologist 95: 295-303.

Schwartzman, S., and B. Zimmerman. 2005. Conservation alliances with indigenous peoples of the Amazon. Conservation Biology 19:721-727. 
Shahabuddin, G., and M. Rao. 2010. Do community-conserved areas effectively conserve biological diversity? Global insights and the Indian context. Biological Conservation 143:2926-2936.

Stearman, A. M. 2006. One step forward, two steps back: the Sirionó and Yuquí Community Forestry Projects in the Bolivian Amazon. Human Organization 65:156-166.

Sunderland, T. C. H., C. Ehringhaus, and B. M. Campbell. 2007. Conservation and development in tropical forest landscapes: a time to face the trade-offs? Environmental Conservation 34:276-279.

Taddei, R. 2011. Watered-down democratization: modernization versus social participation in water management in Northeast Brazil. Agriculture and Human Values 28:109-121.

Taimni, K. 2001. Cooperatives in Asia: from reform to reconstruction. Geneva: International Labour Organization.

Trancuso, R., A. Carneiro Filho, J. Tomasella, J. Schietti, B. R. Forsberg, and R. P. Miller. 2010. Deforestation and conservation in major watersheds of the Brazilian Amazon. Environmental Conservation 36:277-288.

Turner, T. 1995. An indigenous people's struggle for socially equitable and ecologically sustainable production: the Kayapo revolt against extractivism. Journal of Latin American Anthropology 1:98-121.

Vasquéz-León, M. 2006. A study of change strategies among Latin American cooperatives, Year One. Report submitted to ACDI/VOCA. Tucson: Bureau of Applied Research in Anthropology.

Walker, R., N. J. Moore, E. Arima, S. Perz, C. Simmons, M. Caldas, D. Vergara, and C. Bohrer. 2009. Protecting the Amazon with protected areas. Proceedings of the National Academy of Sciences 106:10582-10586.

Weinstein, B. 1983. The Amazon rubber boom, 1850-1920. Stanford: Stanford University Press.

West, P., and D. Brockington. 2006. An anthropological perspective on some unexpected consequences of protected areas. Conservation Biology 20(3): 609-616.

Wilshusen, P. R., S. R. Brechin, C. L. Fortwangler, and P. C. West. 2000. Reinventing a square wheel: critique of a resurgent 'protection paradigm' in international biodiversity conservation. Society and Natural Resources 27: 300-311.

Wolf, E. 1982. Europe and the people without history. Berkeley: University of California Press.

Zanotti, L. C. 2009. Economic diversification and sustainable development: the role non-timber forest products pay in the monetization of Kayapó livelihoods. Journal of Ecological Anthropology 13:26-41.

Zimmerman, B., C. A. Peres, J. R. Malcolm, and T. Turner. 2001. Conservation and development alliances with the Kayapó of south-eastern Amazonia, a tropical forest indigenous people. Environmental Conservation 28:10-22.

\section{Abstract}


Cooperatives have been widely supported as vehicles for community-based conservation and development. However, these organizations are often developed around specific income-generating projects rather than broader considerations of how relations of power and ecological exploitation might be transformed. This article uses the case of AmazonCoop-a cooperative dedicated to the supposedly fair trade of Brazil nuts between Amazonian indigenous people and the multinational corporation The Body Shop-to illustrate how historical political ecology might facilitate the design of more radically transformative cooperatives. Contextualizing AmazonCoop within the history of Amazonian extractivism, and particularly the extraction of wild rubber, reveals the specific mechanisms and processes through which indigenous people have gained and lost power. This analysis thus creates opportunities for thinking more creatively about how contemporary conservation-development schemes might pursue ecologically sustainable and socially just social transformations.

Keywords: cooperatives, fair trade, conservation, development, indigenous people, Brazil

\section{Resumé}

Les coopératives ont été largement pris en charge en raison de leur contribution à la conservation communautaire et le développement. Ces organisations sont souvent organisés autour de projets spécifiques pour générer des revenus. Ils sont moins préoccupés par des considérations plus larges de la façon dont les relations de pouvoir et de l'exploitation écologique pourrait être transformé. Cet article utilise le cas de AmazonCoop-une coopérative dédiée à la commerce équitable des noix du Brésil entre les peuples autochtones d'Amazonie et de la société multinationale The Body Shop. Il illustrer comment l'écologie politique pourrait faciliter la conception des coopératives qui sont tranformative et radicale. Les articles situer AmazonCoop dans l'histoire de l'extractivisme amazonien, et en particulier l'extraction du caoutchouc sauvage. Il révèle les mécanismes et processus spécifiques à travers lesquels les peuples autochtones ont acquis et ont perdu le pouvoir. Cette analyse crée ainsi des opportunités pour penser de manière plus créative à propos des régimes contemporains conservation-développement, et comment ils pourraient poursuivre sur le plan écologique transformations durables et socialement juste de la société.

Mots-clés: coopératives, le commerce équitable, la conservation, le développement, les autochtones, le Brésil

\section{Resumen}

Las cooperativas han sido ampliamente utilizadas como vehículos para proyectos comunitarios de conservación y desarrollo. Sin embargo, estas organizaciones comunmente se desarrollan en torno a proyectos especiíicos para la generación de ingresos en lugar de consideraciones más amplias de cómo las relaciones de poder y la explotación ecológica pueden ser transformados. Este articulo utiliza el caso de AmazonCoopuna cooperativa dedicada a un comercio supuestamente justo de las nueces de Brasil entre los pueblos indígenas amazónicos y la multinacional The Body Shop-para ilustrar cómo la ecología política histórica podría facilitar el diseño de cooperativas mas radicalmente transformativas. Contextualizando AmazonCoop dentro del marco histórico del extractivismo amazónico, y en particular la extracción de caucho silvestre, revela los mecanismos y procesos específicos a través de los cuales los pueblos indígenas han ganado y perdido el poder. En consecuencia, este análisis crea oportunidades para pensar más creativamente sobre cómo esquemas contemporáneos de conservación y desarrollo podrían apuntar a transformaciones sociales que son ecológicamente sostenible y socialmente justo.

Palabras clave: cooperativas, comercio justo, conservación, desarrollo, pueblos indígenas, Brasil 